Agrovoc descriptors: Chrysoperla carnea, neuroptera, feeding habits, larvae, insect nematodes, bioassays, biological control, biological control organisms, environmental factors, population density, temperature, mortality, pest control

Agris category code: $\mathrm{H} 10$

\title{
Effect of temperature on cannibalism rate between green lacewings larvae (Chrysoperla carnea [Stephens], Neuroptera, Chrysopidae)
}

\author{
Helena ROJHT ${ }^{1}$, Franc BUDIJA ${ }^{2}$, Stanislav TRDAN ${ }^{3}$
}

Received November 05, 2008, accepted April 2, 2009.

Delo je prispelo 5. novembra 2008, sprejeto 2. aprila 2009.

\begin{abstract}
Paper presents a larval cannibalism of green lacewings (Chrysoperla carnea), which was observed during the laboratory bioassay on non-target effect of entomopathogenic nematodes against green lacewings larvae. The most probable reason for larval cannibalism were undersized Petri dishes in which the bioassay was performed. Due to large number of larvae per surface unit, frequent crossing of green lacewings larvae appeared and this consequently lead to cannibalism. In most cases larger, elder larvae consumed smaller, younger larvae. Cannibalism increased with temperature rise and was the most intensive at $25{ }^{\circ} \mathrm{C}$. At this temperature the larval mortality was $22.0 \%$ after two days, while after four days the larval mortality reached $31.0 \%$.
\end{abstract}

Key words: larval cannibalism, green lacewings, Chrysoperla carnea, laboratory bioassay, biological control

\author{
VPLIV TEMPERATURE NA STOPNJO \\ KANIBALIZMA MED LIČINKAMI NAVADNE \\ TENČIČARICE (Chrysoperla carnea Stephens, \\ Neuroptera, Chrysopidae)

\section{IZVLEČEK}

$\mathrm{V}$ prispevku je predstavljen kanibalizem med ličinkami navadne tenčičarice (Chrysoperla carnea), ki se je pojavil pri laboratorijskem preučevanju neciljnega delovanja entomopatogenih ogorčic na ličinke omenjenega naravnega sovražnika. Najverjetnejši vzrok za pojav kanibalizma so bile premajhne petrijevke, $\mathrm{v}$ katerih je potekal poskus. Zaradi velikega števila ličink navadne tenčičarice na enoto površine, je prišlo do pogostega srečevanja ličink in posledično do kanibalizma. V večini primerov so ličinke višjega larvalnega stadija pojedle manjše ličinke. Kanibalizem se je povečeval $z$ višanjem temperature in je bil najbolj intenziven pri $25{ }^{\circ} \mathrm{C}$, kjer je bila smrtnost ličink dva dni po začetku poskusa $22,0 \%$, po štirih dneh pa $31,0 \%$.

Ključne besede: kanibalizem, navadna tenčičarica, Chrysoperla carnea, laboratorijski poskus, biotično varstvo

\section{INTRODUCTION}

Cannibalism is a frequent behavior in animals and plays an important role in population dynamics. It is genetically based but controlled or induced by various environmental cues (Polis, 1981). The most frequent types of cannibalism among arthropods are when adults or older larval stages eat juvenile stages or eggs. Not sufficiently protected pupae can be exceptionally cannibalized (Elgar and Crespi, 1992). Sexual cannibalism is appearance where females eat courting males before, during or immediately after copulation (Elgar, 1992; Johns and Maxwell, 1997).

Within the Neuroptera order, cannibalism seems to be correlated with polyphagous feeding habits (Duelli,

\footnotetext{
1 Jamnikarjeva 101, SI-1111 Ljubljana, e-mail: helena.rojht@bf.uni-lj.si

2 Rožna dolina, Cesta VIII/34, SI-1111 Ljubljana, e-mail: franc.budija@bf.uni-lj.si

3 Jamnikarjeva 101, SI-1111 Ljubljana, e-mail: stanislav.trdan@bf.uni-lj.si
} 
1981). Chrysophid larvae are active hunters, characterized by swift movements, aggressive behavior and fast growth. These larvae are voracious and usually polyphagous predators, therefore their diet also includes prey of the same species (Canard, 1984).

An ecological factor that generally favours cannibalism, particularly in entomophagous insects, is a low availability of food, which may depend to varying degrees upon population density (Elgar and Crespi, 1992). Mochizuki et al. (2006) observed $100 \%$ cannibalism among green lacewings larvae in the absence of aphids, but if the aphids were presented, the abundance of the cannibalism was negligible. In most cases happened that the larger, elder, and consequently better fed larvae consumed the smaller, starving, and the younger larvae (Bar and Gerling, 1985). Arzet (1973) reported that after $72 \mathrm{~h}$ of starvation the cannibalism occurred between larvae, which were the same size and age. Bar and Gerling (1985) found out that C. carnea pupae were eaten only by $3^{\text {rd }}$-instar larvae. Cannibalism is a disadvantage in mass production of green lacewings larvae for biological control of plants (van Lenteren, 2003). But in natural conditions when the food is in shortage, the cannibalism is only option for survival of individuals and it is the only possibility to prevent local extinction (McEwen et al., 2001).

The green lacewings larvae are polyphagous insects and they feed on any soft bodies organisms that are small enough for them to capture, including aphids, scales, mealy-bugs, whiteflies, small caterpillars, leafhoppers, psyllids, thrips, mites, insect eggs and mites and others (Olkowski et al., 1996; Strand, 2006). Because the green lacewings larvae are so effective predator of pest insects, they are mass reared and used as biological control agents in America and Europe. Commercial products contain one growth stage (eggs, larvae or pupae) or mixed stages, dependent on producer (van Lenteren, 2003).

\section{MATERIAL AND METHODS}

The investigation of non-target effect of entomopathogenic nematodes on green lacewings larvae was carried out during 2007 in the Entomological Laboratory of the Chair of Entomology and Phytopathology (University of Ljubljana, Biotechnical Faculty, Department of Agronomy) in Ljubljana, Slovenia (Rojht, 2007). In this laboratory bioassay we came across with larval cannibalism. Commercial preparation of $C$. carnea larvae "Chrysopa" was obtained from the Netherlands company Koopert B. V., Berkel en Rodenrijs.

Laboratory tests were performed in Petri dishes with diameter of $7 \mathrm{~cm}$ (Figure 1). On the top of the lid a hole of $2 \mathrm{~cm}$ diameter was made. From the exterior side, it was covered with a dence nylon net, to provide a sufficient air circulation and to prevent escaping the insects. In the bottom of Petri dishes a cellulose paper (producer: Tosama d. d., Slovenia) with the same diameter was placed and then $1 \mathrm{ml}$ of suspension of entomopathogenic nematodes was applied with pipette. Leaves of the plants and aphids were used as food for green lacewings larvae. At the end we put in each Petri dish ten green lacewings larvae, the predators of aphids. Petri dishes were then tightened with parafilm and placed in rearing chamber (type RH-900 CH, producer: Kambič, Semič) for 24 hour's darkness at relative humidity $85 \%$. For each temperature 95 Petri dishes were provided. After second and fourth day the survived larvae of green lacewings and larvae were counted. With counting the missing green lacewings larvae at the same time the larval cannibalism were evaluated.

All statistical analyses (ANOVA, Duncan's multiple range test) were performed using Statgraphics Plus for Windows 4.0 (Manugistics, Rockville, MD, USA) and figure was created with MS Office Excel 2003. The data are presented as untransformed means $\pm \mathrm{SE}$. 
Effect of temperature on cannibalism rate between green lacewings larvae (Chrysoperla carnea [Stephens]...

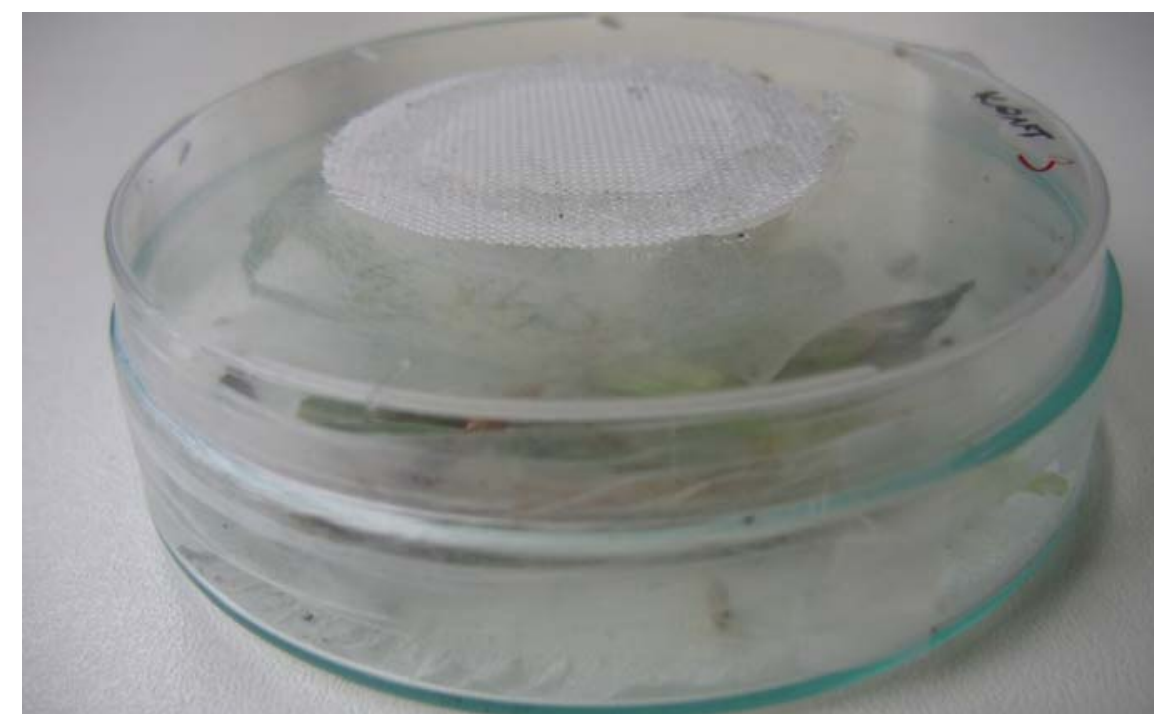

Figure 1: Experimental vessel made for investigation of non-target effect of entomopathogenic nematodes on green lacewings (Chrysopera carnea) larvae. At the same type of vessels the rate of larval cannibalism was investigated (photo: H. Rojht).

\section{RESULTS}

Group analysis indicated a statistically significant effect of temperature $(\mathrm{P}<0.0001)$ and day after treatment $(\mathrm{P}<$ $0.0001)$ on the percentage of cannibalism between green lacewings larvae. The influence of EPN species and nematode concentration were not significant.

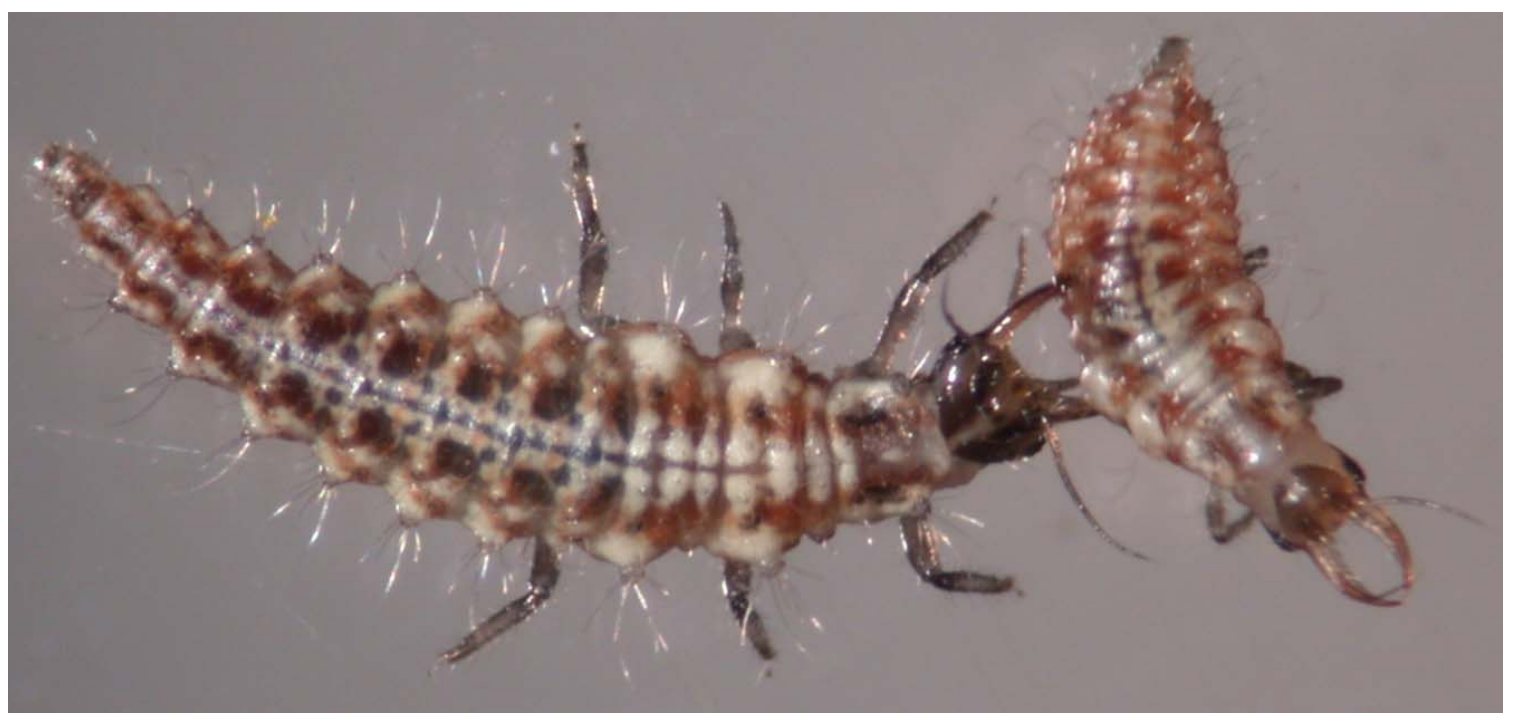

Figure 2: Cannibalism between green lacewing (Chrysopera carnea) larvae. Bigger and elder larva consumed smaller conspecific larva (photo: $H$. Rojht). 


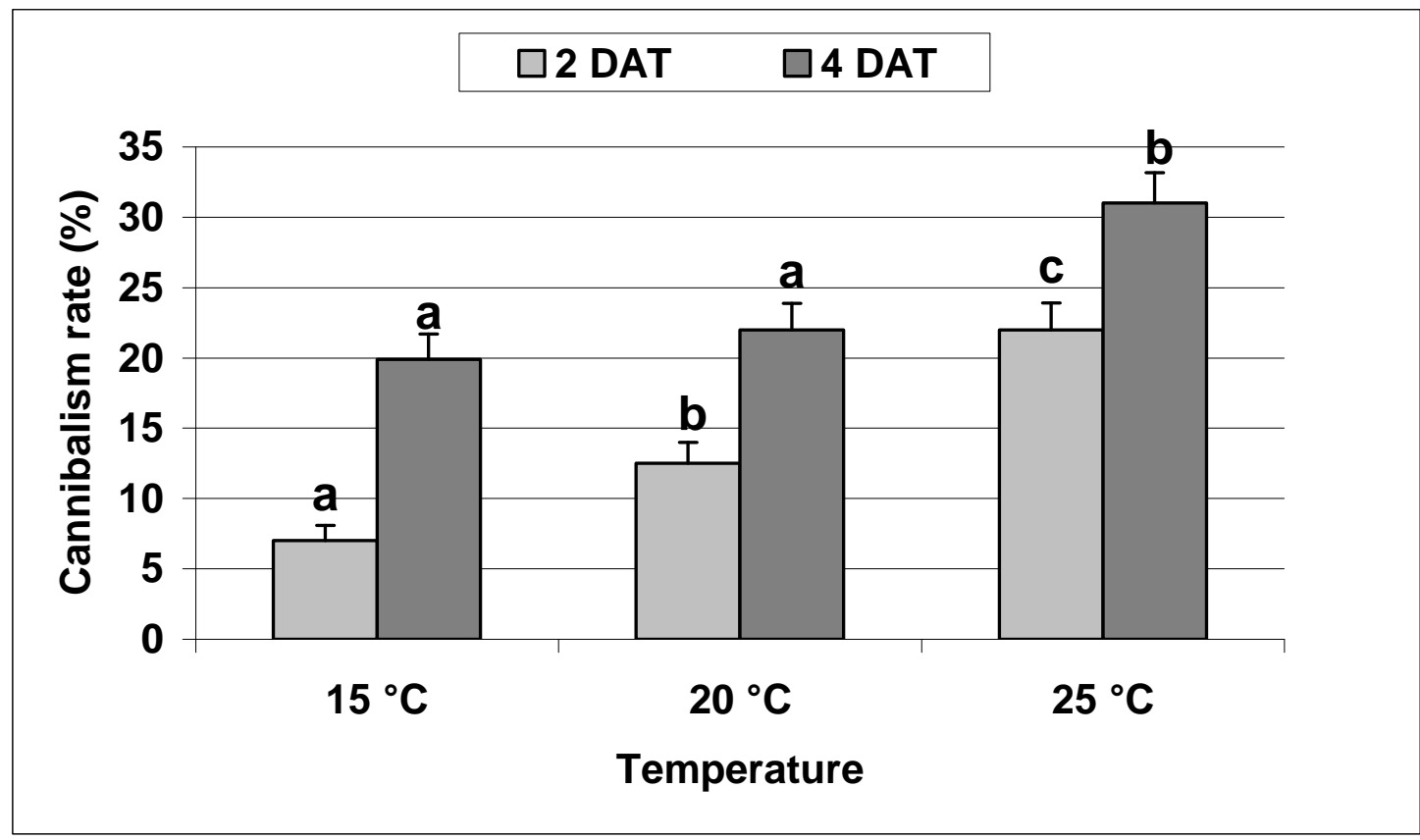

Figure 3: Effect of temperature on cannibalism of green lacewing (Chrysopera carnea) larvae two and four days after exposure. Letters above bars represent statistical significant differences $(P<0.05)$ between percentage of cannibalism within one day, respectively. (DAT = days after treatment)

Appearance of larval cannibalism between green lacewings was abundant. Figure 3 represent the effect of temperature and day after treatment (DAT) on cannibalism abundance. Two $(22.0 \pm 1.9 \%)$, and four days after treatment $(31.0 \pm$ $2.2 \%$ with entomopathogenic nematodes, the most frequent larval cannibalism was recorded at the highest temperature $\left(25^{\circ} \mathrm{C}\right)$. Two days after treatment, the lowest larval cannibalism $(7.0 \pm 1,1 \%)$ was found to be at $15^{\circ} \mathrm{C}$, while four days after treatment no significant differences were found between cannibalism rate at $15(19.9 \pm 1.8 \%)$ and $20^{\circ} \mathrm{C}(22.0 \pm 1.9 \%)$.

\section{DISSCUSSION AND CONCLUSIONS}

Already at the time of receiving the commercial preparation "Chrysopa", we noticed the first signs of larval cannibalism; namely egg-larval and larval-larval cannibalism. The most often cannibalism within larvallarval cannibalism was among larvae of the different size and age, and not cannibalism among larvae of the same size and age. The producer of commercial preparation used suitable stuffing material (husks of buckwheat), which prevented or aggravated contact between C. carnea larvae. Moreover, alternative food was also added and commercial preparation was transfered on low temperature. In spite of all the number of C. carnea larvae in package was for about $25 \%$ lower than designated on declaration. We also assumed that long transfer from Netherlands to Slovenia, and behavior nature of green lacewings larvae had great influence on appearance of cannibalism.

Laboratory studies performed by Kurbanov (1984) showed that relative humidity, photoperiod and temperature was important in mass rearing of C. carnea.
Several authors had given different data about optimal temperature values for rearing C. carnea larvae. For example Orešek (2003) reared green lacewings larvae at average temperature of $28.6^{\circ} \mathrm{C}$, Milevoj (1999) from 23 to $27{ }^{\circ} \mathrm{C}$, and Duelli (1981) at $25 \pm 2{ }^{\circ} \mathrm{C}$. Chiaki and Masashi (1999) reported that the shortest developmental period of one generation of C. carnea was at $25^{\circ} \mathrm{C}$. At this temperature the larval development was high and the need for food was greater. In our research the optimal temperature for development of green lacewings was $25{ }^{\circ} \mathrm{C}$, therefore the larvae were very active and cannibalism the most abundant.

In our research the larval cannibalism between green lacewings was presented frequently, despite instructions from previous laboratory rearing methods of $C$. carnea (Milevoj, 1999), in which the aphids were added in excess, and to prevent the chrysophid larvae from encountering one another, obstacles were placed. Obstacles and excessive amounts of food did not entirely prevent larval 
cannibalism but only extenuated them (Orešek, 2003). In our experiment we wanted to reduce larval cannibalism with addition of excess amounts of aphids; in spite of that, green lacewings larvae were often consumed by other larvae.

Bar and Gerling (1985) found out that larval cannibalism could occur by chance. To consider that fact, we assumed that a possible reason for larval cannibalism could also be too many C. carnea larvae per unit of area. Our experimental pots were obviously too small, therefore the chance of larvae crossing were more often. In such crossing in most of cases the larger, the better fed and the elder larvae consumed the smaller, the hungry and the younger larvae. In the end we can totally exclude larval cannibalism by placing only one green lacewing larvae per one experimental pot, but our scheme of bioassay and laboratory capability did not permit suchlike accession.

\section{ACKNOWLEDGEMENT}

This research was funded by Slovenian Research Agency (Programe Horticulture P4-0013) and Ministry of
Agriculture, Food and Forestry of Republic Slovenia (L46477).

\section{REFERENCES}

Arzet, H. R. (1973): Suchverhalten der Larven von Chrysopa carnea Steph. (Neuroptera: Chrysopidae). Z. Angew. Entomol., 74: 64-79.

Bar, D., Gerling D. (1985): Cannibalism in Chrysoperla carnea (Stephens) (Neuroptera, Chrysopidae). Isr. J. Entomol., 19: 13-22.

Chiaki, F., Masashi, N. (1999): Effects of photoperiod and temperature on larval development of Chrysoperla carnea Stephens (Neuroptera: Chrysopidae). Jpn. J. Appl. Entomol. Zool., 43: 175-179.

Duelli, P. (1981): Is larval cannibalism in lacewings adaptive? (Neuroptera: Chrysopidae). Res. Popul. Ecol., 23: 193-209.

Elgar, M.A. (1992): Sexual cannibalism in spiders and other invertebrates. In: Cannibalism: Ecology and evolution among diverse taxa. Elgar M. A. and Crespi B. E. (eds). Oxford University Press: $361 \mathrm{p}$.

Elgar, M.A., Crespi, B.J. (1992): Cannibalism. Ecology and evolution among diverse taxa. Oxford University Press, Oxford, UK.: 361 p.

Johns, P.M., Maxwell, M.R. (1997): Sexual cannibalism: who benefits? Trends Ecol. \& Evol., 12: 127-128.

McEwen, P., New, T.R., Whittington. A. (2001): Lacewings in the crop environment. Cambridge University Press: 564 p.

Milevoj, L. (1999): Rearing of the common green lacewing, Chrysoperla carnea Stephens, in the laboratory. Zb. Bioteh. fak. Univ. Ljubl., Kmet., 73: 65-70.
Mochizuki, A., Naka, H., Hamasaki, K., Mitsunaga, T. (2006): Larval cannibalism and intraguild predation between the introduced green lacewing, Chrysoperla carnea, and the indigenous trash-carrying green lacewing, Mallada desjardinsi (Neuroptera: Chrysopidae), as a case study of potential nontarget effect assessment. Environ. Entomol., 35: 1298-1303.

Olkowski, W., Daar, S., Olkowski, H. (1996): The Gardener's Guide to Common-Sense Pest Control. Taunton Press, 320 p.

Orešek, E. (2003): Razširjenost tenčičaric (Chrysopidae) v intenzivnem sadovnjaku in prehranske zahteve vrst Chrysoperla carnea (Stephens) (Neuroptera, Chrysopidae). Magistrsko delo. Ljubl., Bioteh. fak., Oddel. agron.: 85 p.

Polis, G.A. (1981): The evolution and dynamics of intraspecific predation. Annu. Rev. Ecol. Syst., 12: 225-251.

Rojht, H. (2007): Neciljno delovanje entomopatogenih ogorčic (Rhabditida) na izbrane plenilce pravih listnih uši (Aphididae). Magistrsko delo. Ljubl., Bioteh. fak., Oddel. agron.: $84 \mathrm{p}$.

Strand, L. (2006): Integrated pest management for potatoes in the western united states. ANR Publ., 167 p.

van Lenteren, J.C. (2003): Quality control and production of biological control agents: theory and testing procedures. CABI Publishing: $327 \mathrm{p}$. 